\author{
Research Article
}

\title{
A COMPARATIVE CLINICAL STUDY ON VAMANA AND VIRECHANA KARMA IN THE MANAGEMENT OF EKAKUSHTHA WITH SPECIAL REFERENCE TO PSORIASIS
}

\section{Haidar $^{*}$, Sukumar Ghosh ${ }^{2}$, Supriya Bhattacharya ${ }^{3}$, Asish Kumar Das ${ }^{4}$, Rajarshi Chaudhuri ${ }^{5}$}

*1Post Graduate Scholar, ${ }^{2}$ Professor and H.O.D, ${ }^{3}$ Ex-Professor, ${ }^{4}$ Reader, 5 Lecturer, Department of Panchakarma, Institute of Post Graduate Ayurvedic Education \& Research at Shyamadas Vaidya Shastra Pith, Kolkata, West Bengal, India.

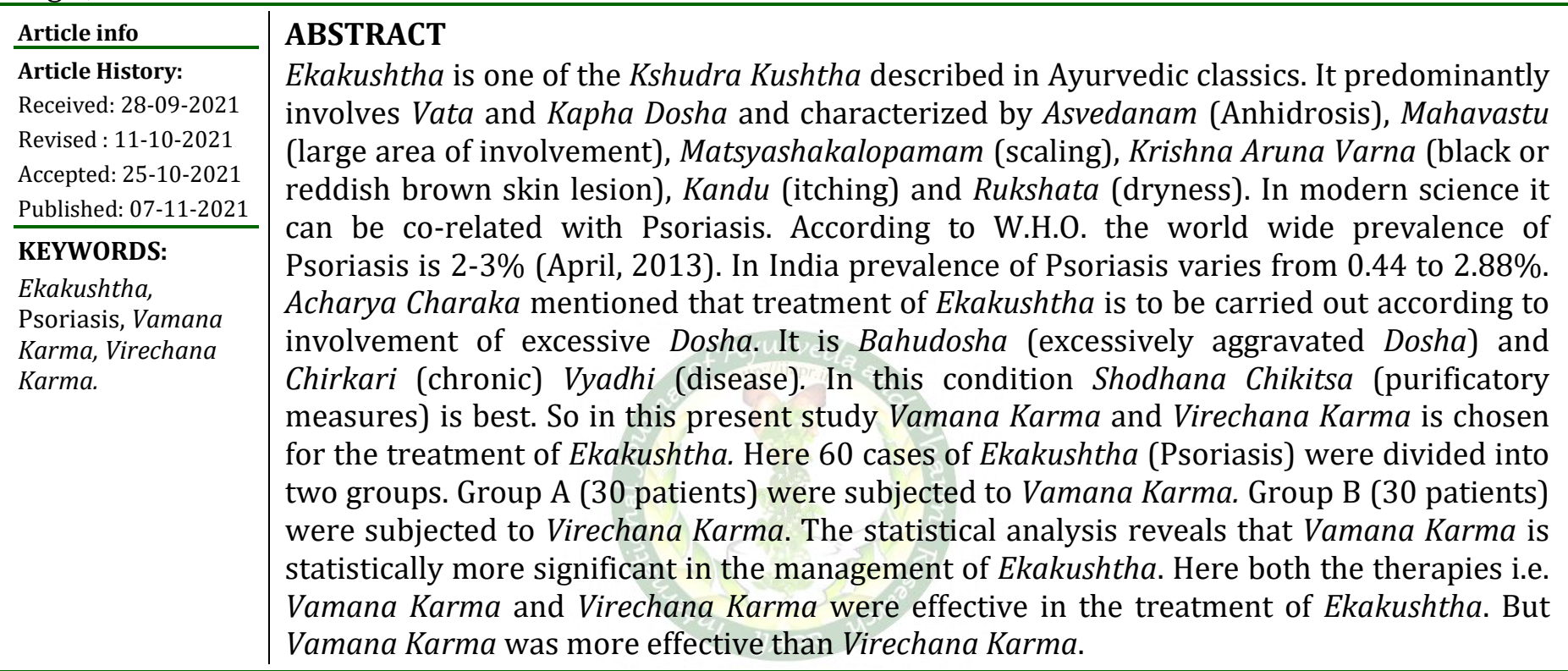

\section{INTRODUCTION}

Ayurveda is a science of life with aim of protection of health and alleviation of disease. It provides a disease free and healthy environment. Any ugliness or disease condition of the skin gives rise to both physiological and psychological illness to the patient.

Ekakushtha, a type of skin disease, is one of the Kshudra Kushtha described in Ayurvedic classics. It predominantly involves Vata and Kapha Dosha and characterized by Asvedanam (Anhidrosis), Mahavastu (large area of involvement), Matsyashakalopamam (scaling), Krishna Aruna Varna (black or reddish brown skin lesion), Kandu (itching) and Rukshata

\begin{tabular}{|l|l|}
\hline \multicolumn{3}{|c|}{ Access this article online } \\
\hline Quick Response Code & \begin{tabular}{l} 
https://doi.org/10.47070/ijapr.v9iSuppl1.2109 \\
\hline
\end{tabular} \\
\cline { 2 - 2 }
\end{tabular}

(dryness).[1] Most of the features of Ekakushtha are more or less similar to Psoriasis. Psoriasis is an autoimmune, non-infectious, chronic inflammatory skin disorder where altered keratinization of epidermal cell takes place with well- defined erythematous lesion and silvery plaques with a predilection for the extensor surface and scalp and a chronic fluctuating course. ${ }^{[2]}$ According to WHO, the world wide prevalence of Psoriasis is 2-3\% (April, 2013). In India prevalence of Psoriasis varies from 0.44 to $2.88 \%{ }^{[3]}$

Modern medical treats psoriasis with corticosteroids, PUVA and immunosuppressant. But this management gives grave side-effects like obesity, bone marrow depletion, hepatotoxicity and nephrotoxicity etc. Hence it is the need of time to find out safe and effective treatment for Ekakushtha in Ayurveda.

In the context of Kushtha, Acharya mentioned that treatment is to be carried out according to involvement of excessive Dosha. ${ }^{[4]}$ Ekakushtha is Vata 
Kaphaja Pradhana Tridoshaja Raktagata Chirkari Vyadhi. Shodhana Chikitsa is best for Bahudosha and Chirkari Vyadhi..[4] So for treatment of Kapha Dushti, Vamana is best and for treatment of Raktagata Vyadhi, Virechana is best Shodhana Chikitsa.[5]

\section{AIM AND OBJECTIVES}

Aim: To compare the efficacy of Vamana Karma and Virechana Karma in the management of Ekakushtha.

\section{Objectives}

1. To evaluate the effect of Vamana Karma in the management of Ekakushtha.

2. To evaluate the effect of Virechana Karma in the management of Ekakushtha.

MATERIALS AND METHODS

Approval by Institutional Ethical Committee for Clinical Trial on Human subjects (memo no. SVP/334/2019) got on 16.05.2019. Patients were selected from the OPD \& IPD of Panchakarma Department of Institute of Post Graduate Ayurvedic Education \& Research at S.V.S.P., Kolkata, on the basis of clinical criteria full filing the diagnosis of Ekakushtha with special reference to Psoriasis as per description of Ayurvedic text and standard textbook of Modern medicine.

In a specified research format, the consent of patient with signature or left thumb impression and date were taken. Patients were diagnosed and assessed thoroughly on the basis of Ayurvedic classical signs and symptoms and were examined on the basis of specially prepared proforma along with a detailed history.

\section{Inclusion Criteria}

- Patients having classical Lakshana of Ekakushtha.[1]

- Patients fit for Vamana Karma and Virechana Karma.

- Patients of either sex of age group between 18-60 years.

- Patients who are willing to undergo the therapy.

\section{Exclusion Criteria}

- Age group less than 18 years and more than 60 years.

\section{Criteria for Assessment}

Improvement in signs and symptoms were appraised on the basis of adopted scoring pattern.

\begin{tabular}{|c|l|}
\hline S. No. & Assessment criteria \\
\hline 1. & Asvedanama (Anhidrosis) \\
& 0- Normal sweating \\
& 1- Mild sweating \\
& 2- Mild sweating after exercise \\
& 3- No sweating after exercise \\
\hline 2. & Mahavastu (Large area involved) \\
& 0- No lesions on body \\
& 1- Partial lesions on hand, neck, scalp, trunk, back \\
& 2- Lesions on most part of the hand, leg, neck, scalp, trunk, back \\
& 3- Lesions on all parts of body \\
\hline
\end{tabular}

- Patients suffering from Uncontrolled Diabetes mellitus, Hypertension, Hridroga and other systemic diseases.

- Patients who are contraindicated for Vamana Karma and Virechana Karma.

\section{Plan of Study}

Patients were divided into two groups consisting of thirty each.

\section{Group A: 30 patients were treated with Vamana Karma}

Purvakarma: For Dipana, Pachana Panchakola Churna $5 \mathrm{gm}$ thrice daily before food with lukewarm water till Niramavastha was obtained.

Snehana: Arohana Krama Snehapana with Panchatikta Ghrita starting from $30 \mathrm{ml}$ till the Samyaka Snigdha Lakshana seen or 7 days whichever is earlier, then Abhyanga by Nimba Taila followed by Sarvanga Sveda.

Pradhana Karma: Akanthapana of milk were given prior to administration of Vamaka Yoga.

Vamaka Yoga: Madanaphala Pippali Churna, Saindhava, Vacha, Madhu.

Dose: As per Roga Bala and Rogi Bala.

Pashchat Karma: Peyadi Samsarjana Krama was followed according to Shuddhi.

Group B: 30 patients were treated with Virechana Karma.

Purva karma: Same as Group A i.e. Vamana Karma.

Pradhana Karma: Virechana by Trivritta Avaleha was done.

Dose: As per Roga Bala and Rogi Bala.

Pashchat karma: Same as Group A i.e., Vamana Karma.

Patients were examined on the basis of questionnaire put in proforma. Etiopathology of the ailment was studied on the basis of clinical history given by the patient and assessments were recorded in proforma. Improvement in signs and symptoms were appraised on the basis of adapted scoring pattern. 


\begin{tabular}{|c|c|}
\hline & 4- Lesions on the whole body \\
\hline 3. & 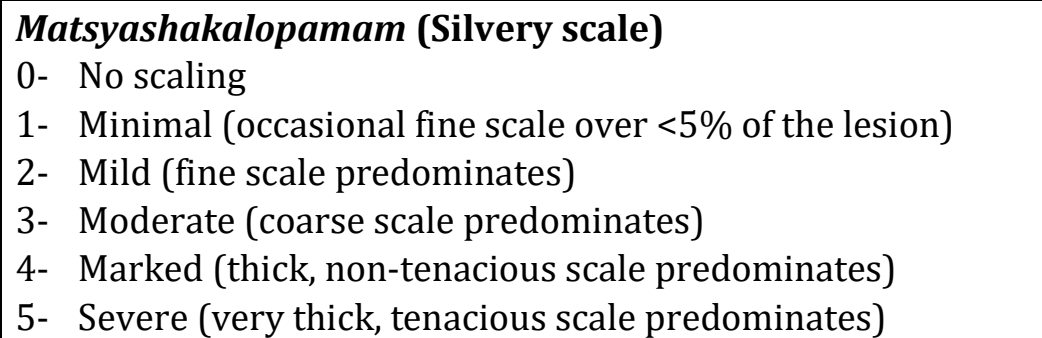 \\
\hline 4. & 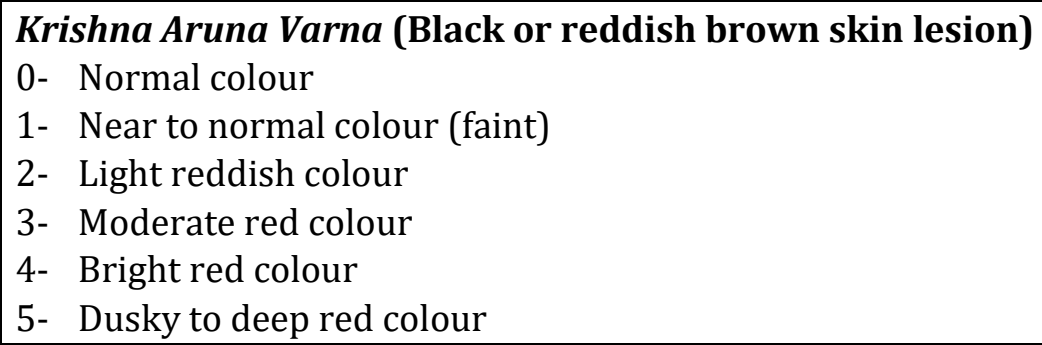 \\
\hline 5. & $\begin{array}{l}\text { Kandu (Itching) } \\
0-\quad \text { No itching } \\
\text { 1- Mild / occasional itching } \\
\text { 2- } \text { Moderate (tolerable) infrequent } \\
\text { 3- } \quad \text { Severe itching frequently } \\
\text { 4- } \quad \text { Very severe itching disturbing sleep and other activities } \\
\end{array}$ \\
\hline 6. & $\begin{array}{l}\text { Rukshata (Dryness) } \\
0-\quad \text { No line on scratching with nail } \\
\text { 1- } \quad \text { Faint lines on scratching with nail } \\
\text { 2- } \text { Lines and even words can be written on scratching by nail } \\
\text { 3- Excessive Rukshata leading to Kandu } \\
\text { 4- } \quad \text { Rukshata leading to crack formation } \\
\end{array}$ \\
\hline 7. & 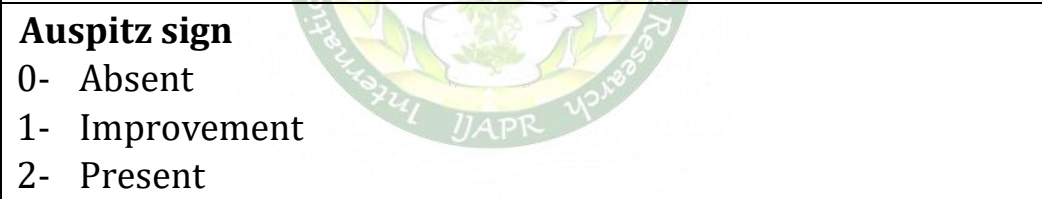 \\
\hline 8. & $\begin{array}{l}\text { Candle grease sign } \\
0-\text { Absent } \\
\text { 1- Improvement } \\
\text { 2- } \text { Present }\end{array}$ \\
\hline
\end{tabular}

\section{Criteria for the Assessment of Overall effect of the Therapies}

a) Complete remission: $100 \%$ relief in the sign and symptoms.

b) Marked improvement: $>75 \%-<100 \%$ relief in the sign and symptoms.

c) Moderate improvement: $>50 \%-<75 \%$ relief in the sign and symptoms.

d) Mild improvement: $>25 \%-<50 \%$ relief in the sign and symptoms.

Insignificant improvement: Below 25\% relief in the sign and symptoms.

\section{Statistical Analysis}

Paired " $\mathrm{t}$ " test was used for statistical analysis.

\section{OBSERVATIONS AND RESULTS}

The effect of treatment was observed on the basis of percentage of relief, SD, SE, $t$ value and $\mathrm{P}$ value. The obtained outcomes were evaluated as -

- Insignificant $-\mathrm{P}>0.5$

- Significant- $\mathrm{P}<0.5<0.01$

- Highly significant- $\mathrm{P}<0.001$ 
Int. J. Ayur. Pharma Research, 2021;9(Suppl 1):27-35

Table No 1: Statistical data showing effectiveness of Vamana Karma in Group A patients of Ekakushtha (Psoriasis)

\begin{tabular}{|c|c|c|c|c|c|c|c|c|c|}
\hline \multirow[t]{2}{*}{ Parameters } & \multirow[t]{2}{*}{$\mathbf{n}$} & \multicolumn{2}{|c|}{ Mean Score } & \multirow[t]{2}{*}{ MD } & \multirow{2}{*}{$\begin{array}{l}\% \text { of } \\
\text { Relief }\end{array}$} & \multirow[t]{2}{*}{ SD } & \multirow[t]{2}{*}{ SE } & \multirow{2}{*}{$\begin{array}{c}\text { 't' } \\
\text { value }\end{array}$} & \multirow[t]{2}{*}{ 'P' value } \\
\hline & & BT & AT & & & & & & \\
\hline Asvedanama & 15 & 1.733 & 0.666 & 1.066 & $62 \%$ & 0.457 & 0.118 & 9.03 & $<0.001$ \\
\hline Mahavastu & 20 & 2.05 & 1.05 & 1.00 & $49 \%$ & 0.458 & 0.10 & 10 & $<0.001$ \\
\hline Matsyashakalopamam & 30 & 2.166 & 0.833 & 1.33 & $61.53 \%$ & 0.801 & 0.146 & 9.109 & $<0.001$ \\
\hline Krishna Aruna Varna & 27 & 2.51 & 1.22 & 1.296 & $51.63 \%$ & 0.947 & 0.182 & 7.12 & $<0.001$ \\
\hline Kandu & 30 & 2.00 & 0.66 & 1.366 & $68.30 \%$ & 0.764 & 0.139 & 9.827 & $<0.001$ \\
\hline Rukshata & 28 & 2.32 & 1.03 & 1.28 & $55.17 \%$ & 0.762 & 0.144 & 8.88 & $<0.001$ \\
\hline Candle grease Sign & 30 & 1.33 & 0.60 & 0.733 & $55 \%$ & 0.583 & 0.106 & 6.91 & $<0.001$ \\
\hline Auspitz’s Sign & 30 & 1.43 & 0.633 & 0.8 & $56 \%$ & 0.609 & 0.111 & 7.20 & $<0.001$ \\
\hline
\end{tabular}

It is evident from the table no.1 that among all the parameters of Ekakushtha (psoriasis) in Group A like Asvedanama, Mahavastu, Matsyashakalopamam, Krishna Aruna Varna, Kandu, Rukshata, Candle grease Sign, Auspitz's Sign; the result was statistically highly significant i.e., $\mathrm{p}<0.001$. This is shown in the following graph.

\section{Effect of Vamana Karma on parameters of Group-A patients}

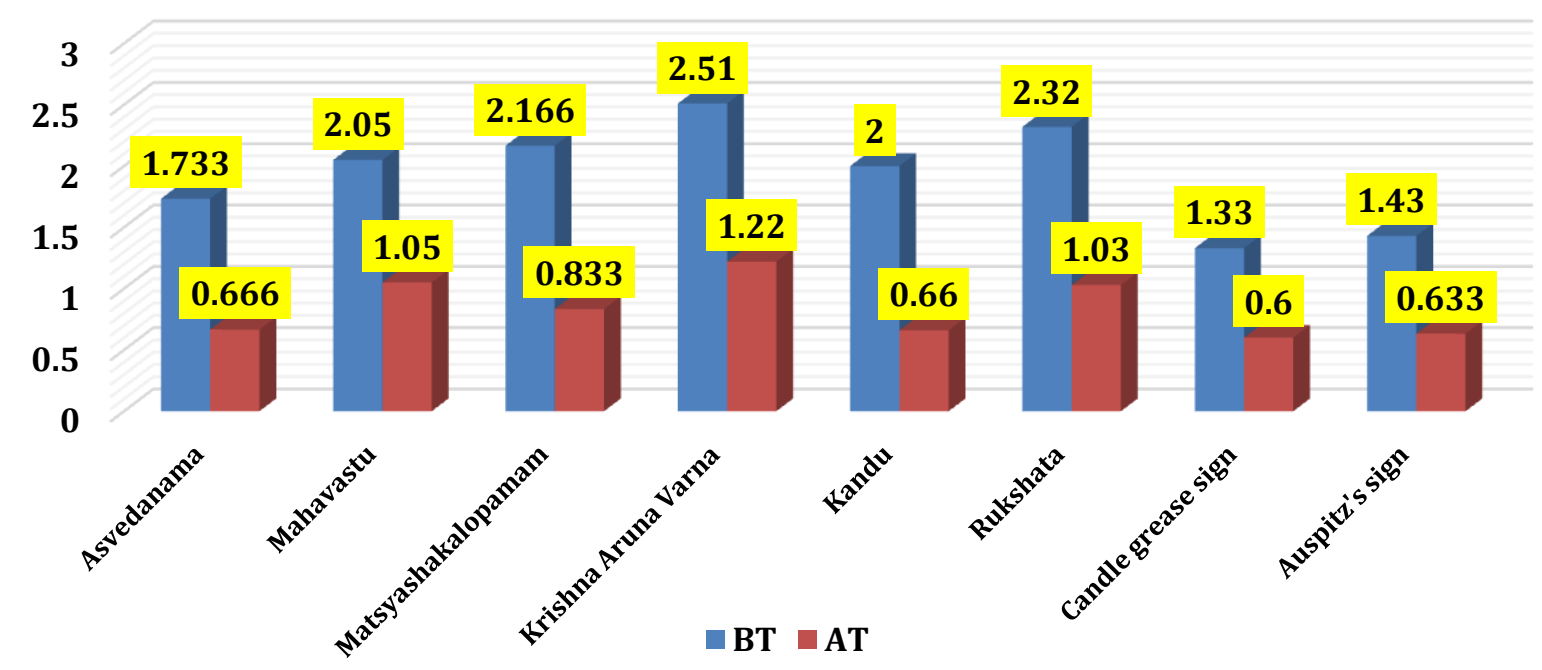

Table No 2: Statistical data showing effectiveness of Virechana Karma in Group B patients of Ekakushtha (Psoriasis)

\begin{tabular}{|c|c|c|c|c|c|c|c|c|c|}
\hline \multirow[b]{2}{*}{ Parameters } & \multirow[t]{2}{*}{$\mathbf{n}$} & \multicolumn{2}{|c|}{ Mean Score } & \multirow[t]{2}{*}{ MD } & \multirow{2}{*}{$\begin{array}{l}\% \text { of } \\
\text { Relief }\end{array}$} & \multirow[t]{2}{*}{ SD } & \multirow[t]{2}{*}{ SE } & \multirow{2}{*}{$\begin{array}{c}\text { 't' } \\
\text { value }\end{array}$} & \multirow[t]{2}{*}{ 'P' value } \\
\hline & & BT & AT & & & & & & \\
\hline Asvedanama & 18 & 1.44 & 1.00 & 0.44 & $30.5 \%$ & 0.615 & 0.144 & 3.05 & $<0.01$ \\
\hline Mahavastu & 29 & 2.10 & 1.65 & 0.44 & $21.31 \%$ & 0.782 & 0.145 & 3.089 & $<0.01$ \\
\hline Matsyashakalopamam & 28 & 2.42 & 1.785 & 0.642 & $26.47 \%$ & 0.825 & 0.186 & 3.45 & $<0.01$ \\
\hline Krishna Aruna Varna & 30 & 2.26 & 1.733 & 0.533 & $23.52 \%$ & 0.899 & 0.164 & 3.25 & $<0.01$ \\
\hline Kandu & 30 & 2.133 & 1.6 & 0.533 & $25 \%$ & 0.899 & 0.164 & 3.25 & $<0.01$ \\
\hline Rukshata & 24 & 2.16 & 1.70 & 0.455 & $21 \%$ & 0.778 & 0.158 & 2.898 & $<0.01$ \\
\hline Candle grease Sign & 30 & 1.5 & 1.1 & 0.4 & $26.66 \%$ & 0.770 & 0.140 & 2.85 & $<0.01$ \\
\hline Auspitz's Sign & 25 & 1.25 & 1.08 & 0.44 & $28.9 \%$ & 0.893 & 0.178 & 2.471 & $<0.05$ \\
\hline
\end{tabular}

It is evident from the table no. 2, that among the parameters of Ekakushtha (Psoriasis) in Group B Asvedanama, Mahavastu, Matsyashakalopamam, Krishna Aruna Varna, Kandu, Rukshata, Candle grease Sign, 
Auspitz's Sign; the result was statistically significant i.e., p<0.01. Auspitz's sign also was statistically significant i.e., $\mathrm{p}<0.05$.This is shown in following graph.

\section{Effect of Virechana Karma on parameters of Group-B patients}

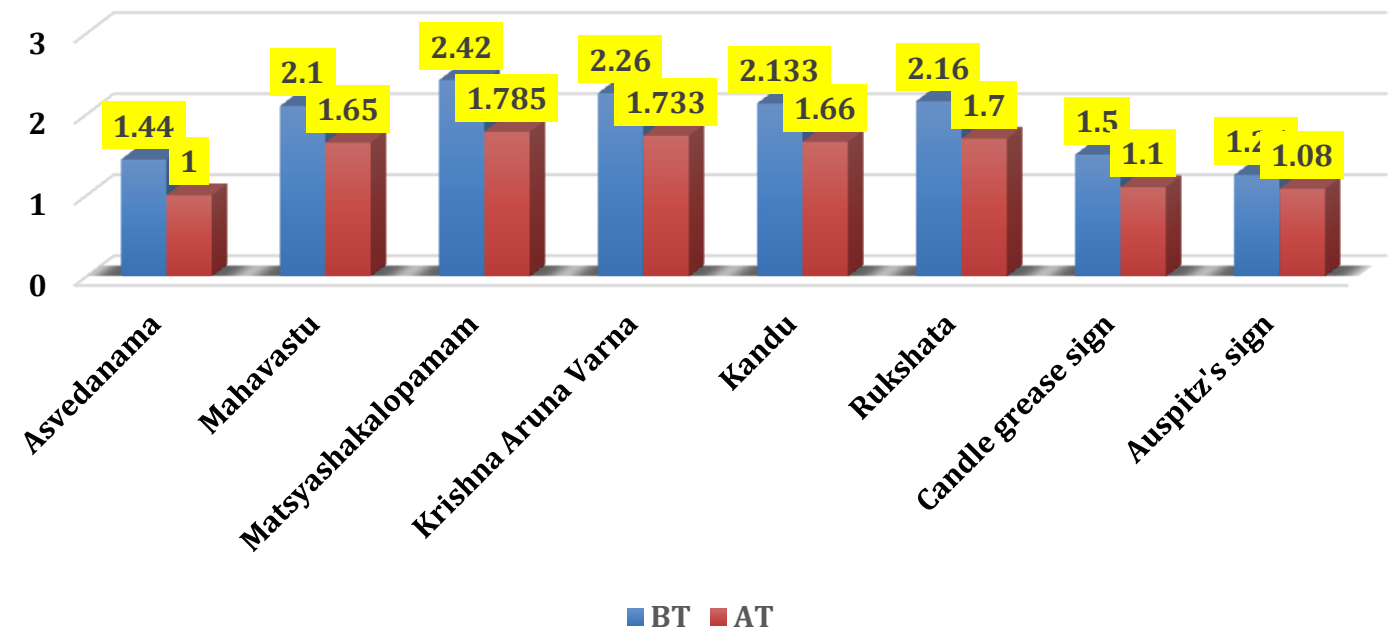

Table No.3: Overall effect of therapy-

\begin{tabular}{|l|c|c|c|c|c|}
\hline Result & Group A & \% & Group B & \% & Total \% \\
\hline Complete remission $(100 \%$ relief) & 0 & $0 \%$ & 0 & $0 \%$ & $0 \%$ \\
\hline Marked improvement $(>75 \%-<100 \%)$ & 8 & $26.66 \%$ & 0 & $0 \%$ & $13 \%$ \\
\hline Moderate improvement $(>50 \%-<75 \%)$ & 19 & $63.33 \%$ & 3 & $10 \%$ & $36.66 \%$ \\
\hline Mild improvement $(>25 \%-<50 \%)$ & 3 & $10 \%$ & 18 & $60 \%$ & $35 \%$ \\
\hline Insignificant improvement $(<25 \%)$ & 0 & $0 \%$ & 9 & $30 \%$ & $15 \%$ \\
\hline Total & 30 & $100 \%$ & 30 & $100 \%$ & $100 \%$ \\
\hline
\end{tabular}

It is noticeable from the table no.3 that:

$>$ Marked improvement was found in $26.66 \%$ of patients in group A, while it was $0 \%$ in patients in Group B.

$>$ Moderate improvement was found in $63.33 \%$ of patients in Group A, while it was $10 \%$ of patients in Group B.

$>$ Mild Improvement was found in $10 \%$ of patients in Group A, while it was $60 \%$ of patients in Group B.

$>$ Insignificant improvement was found in $30 \%$ of patients in group $B$.

$>$ Complete remission was not found in any patient.

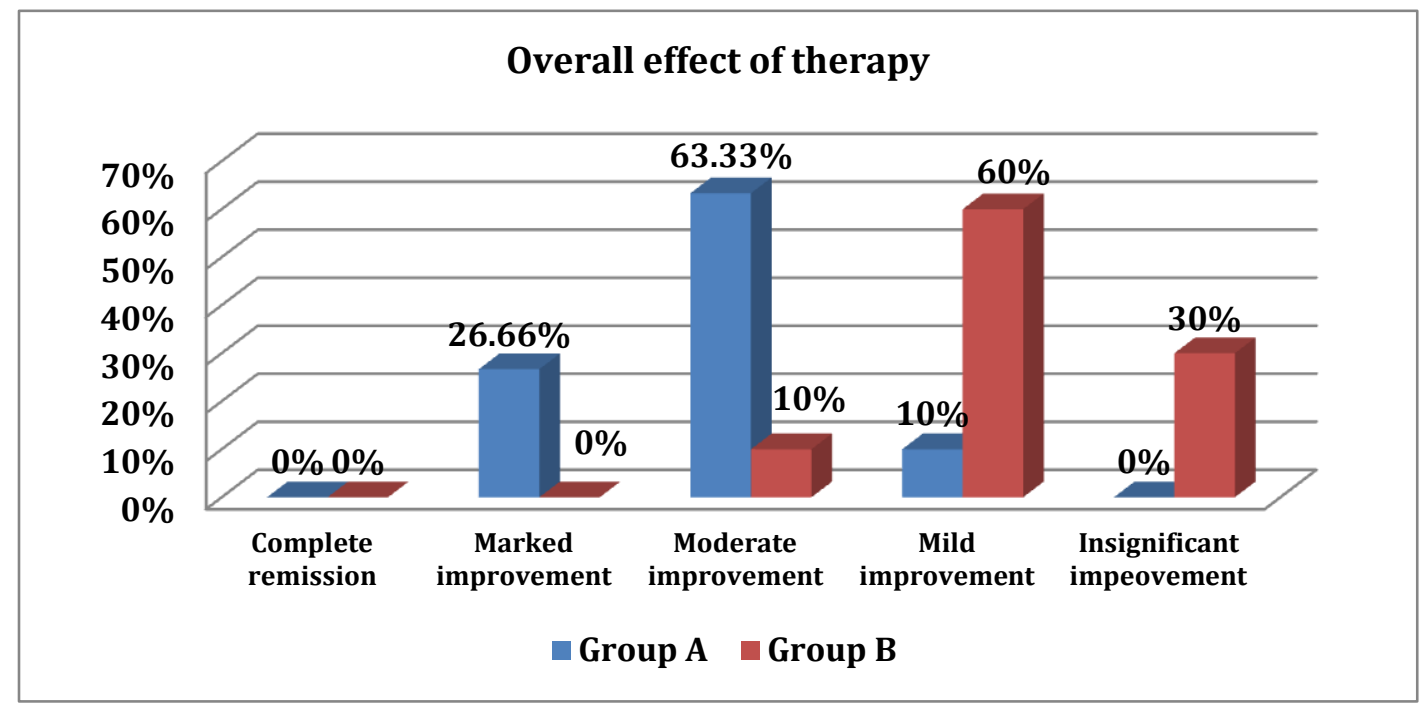




\section{Photographs -Group A}

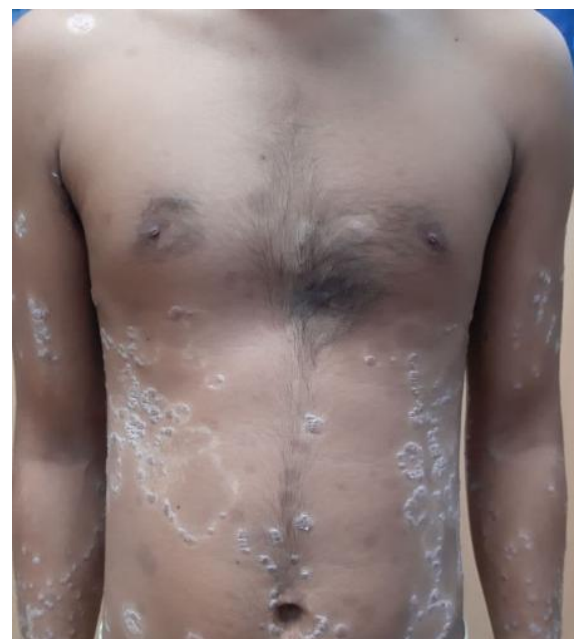

Figure 1: Before Treatment- Abdomen

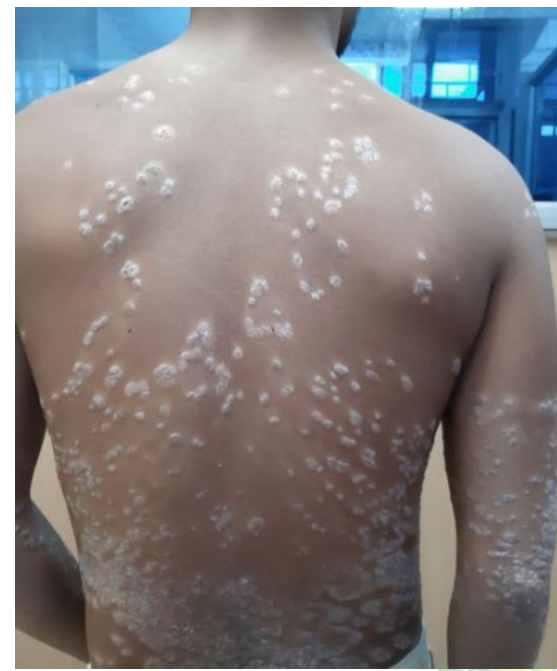

Fig. 3: Before Treatment- Back

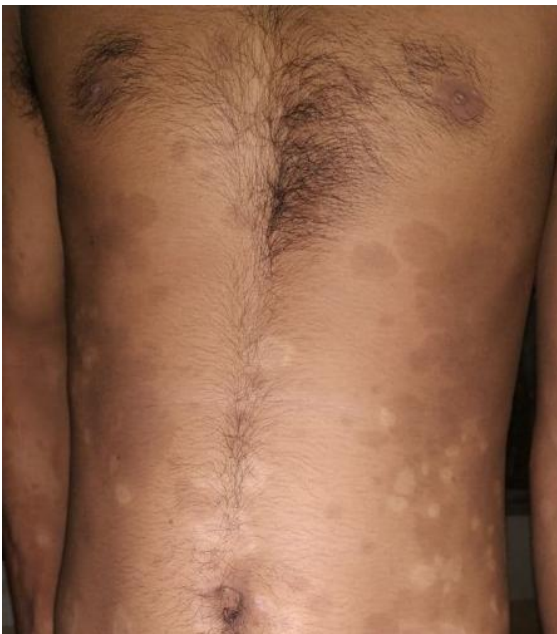

Figure 2: After Treatment- Abdomen

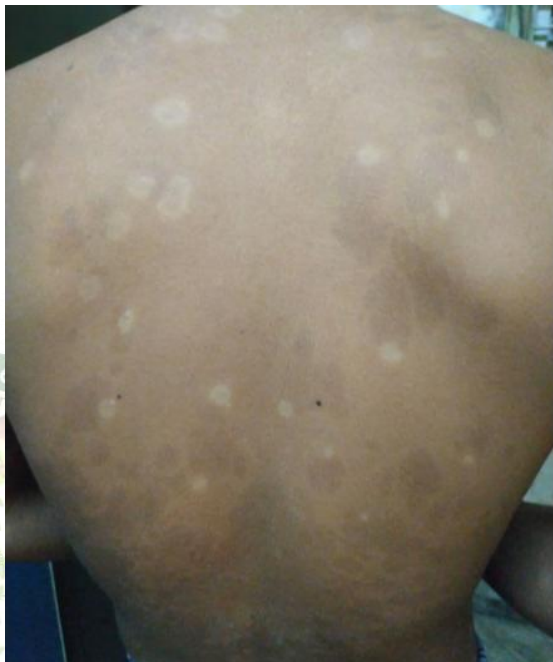

Fig. 4: After Treatment- Back Photographs -Group B

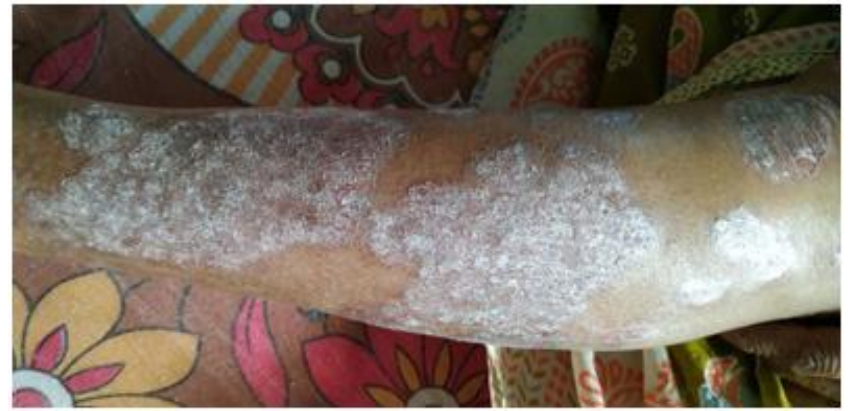

Fig. 5: Before Treatment- Left leg

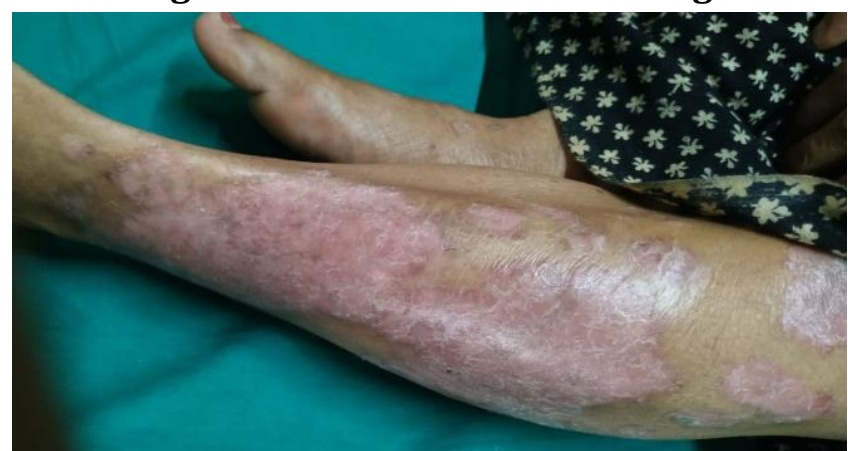

Fig. 6: After Treatment- Left leg 


\section{DISCUSSION}

\section{Discussion on Disease}

Kushtha, as skin disfigurement was found since ancient time. Kushtha is a broad term for all skin diseases. A separate chapter of Kushtha has been mentioned. Ekakushtha is one among the 11 Kshudra Kushtha with vitiation of Kapha \& Vata Dosha and Rakta.[1] Due to Mithyahara, Vihara and Karma, Tridosha gets vitiated affecting Tvaka, Rakta, Mamsa and Ambu and thus manifests Kushtha.[6]

In the context of Kushtha, Acharya mentioned that treatment is to be carried out according to the predominance of Dosha. Ekakushtha, a type of Kshudra Kushtha is Vata Kaphaja Pradhana Tridoshaja Raktagata Vyadhi.[1] So for treatment of Kapha Dushti, Vamana is best and for treatment of Raktagata Vyadhi, Virechana is best Shodhana Chikitsa. ${ }^{[5]}$

\section{Discussion on Therapy}

The Vamana and Virechana Dravya possess the properties Ushna, Tikshna, Sukshma, Vyavayi and Vikashi. Due to its Vyavayi and Vikashi they get quickly spread into all channels of the body. It permeates whole body with the help of its Ushna and Tikshna Guna the accumulated Doshas gets liquefied and breakup into small pieces at cellular level. Tikshna Guna carries the particles which are broken down and separated from Shakha to Koshtha due to the Anupravana Bhava (nature of flow in small channels) of the drugs. Sukshma property makes the pathway for the Virechana drugs to reach minute channels \& remove the morbid matter from them to reach Amashaya in the process of Virechana. Due to Vyavayi property, Virechana drugs get absorbed and spread for further action quickly.

The Vikashi Guna detaches the Mala. Due to the presence of Sukshma Guna and Anupravana Guna the Mala or Dosha float because already body has got Samyaka Snigdhata and pass through smallest capillaries and ultimately reaches to Amashaya. Vamana Dravya are predominant of Agni and Vayu with Urdhvabhagahara Prabhava. Thus Vamaka Aushadhi and excess Dosha expels out through mouth. Virechaka Dravya are predominant of Apa and Prithvi with Adhohagahara Prabhava. Thus Virechaka Aushadhi and excess Dosha expels out through anus.[7]

\section{Discussion on Drugs}

Panchakola Churna: Panchakola Churna was selected for Dipana \& Pachana as it is best for Dipana \& Pachana and also pacifies Vata and Kapha Dosha which is involved in Ekakushtha. ${ }^{[8]}$

Panchatikta Ghrita: It contains Tikta Rasa Dravya. The Tikta Rasa pacifies Sveda, Kandu, Kushtha, Daha and helps in Sthirikarana (stability of the body). Kushtha is a Tridoshaja Raktagata Vyadhi. Tikta Rasa mitigate Pitta \& Kapha Dosha and improve blood circulation (Rakta Prasadana).[9]

Nimba Taila: It has Pittakaphaghna and Kushthaghna property. It also pacifies Vata Dosha and causes Snehana in the body by its Snigdha Guna. As Nimba is Tikta Rasa Pradhana Dravya it has Kandughna property.[10]

Madanaphala: Among all Vamaka Dravya Madanaphla is best because of Anapayitvat i.e., in comparison to other Vamaka Dravya it causes less complication.[11]

Trivritta Lehyam: Trivritta Lehyam was selected for Virechana Karma as it is considered as best Sukhavirechana Dravya.[5]

\section{Discussion on Observation}

Marital status: It reveals that maximum patients were belonging to married group. The total incidences were $80 \%$ followed by next higher incidence from the group of unmarried i.e., $15 \%$. Since after marriage subjects are more prone to mental stress, familial and social burden and also have various types of addiction, the disease is more in adult married person as the above mentioned are aggravating factors for disease Ekakushtha (Psoriasis).

Chief Complaint: It was observed that $100 \%$ patients were suffering from Kandu (itching). Other incidence observed were Matsyashakalopamam (silvery scale) 96.66\%, Krishna Aruna Varna 95\%, Rukshata (Dryness) i.e. 86.66\%, Mahavastu (large area involved) $81.66 \%$. Then the least incidence observed Asvedanama i.e., 55\%. Aggravated Vata Dosha causes Rukshata of Tvaka which causes Kandu (itching) at the affected area of the body. So it can be interpreted that Kandu (itching), Matsyashakalopamam (silvery scale), Rukshata (dryness) are chief complaint of the disease Ekakushtha. It was observed that $100 \%$ of patients were presented with Candle grease sign followed by 91.66\% patients were presented with Auspitz sign. So it can be interpreted that both Candle grease sign and Auspitz sign generally present in case of Psoriasis.

Type of Psoriasis: It was found that maximum patients were suffering from Chronic plaque type of Psoriasis i.e., 56.66\%, next were generalised Psoriasis i.e. $16.66 \%$, followed by localised Psoriasis i.e., $13.33 \%$, followed by Flexural Psoriasis i.e., 8.33\%, followed by Guttae Psoriasis i.e., 8.33\%. There was no patient of Pustular Psoriasis.

Chronicity of Illness: In this study, maximum patients i.e. $48.33 \%$ were suffering from the disease ranges from 4 years-10 years. So it can be concluded that Ekakushtha (Psoriasis) is chronic disease.

Aggravating Factors: This study reveals that 58.33\% reported winter as an important aggravating factor, while $26.66 \%$ said emotional stress was aggravating factor. $10 \%$ considered exposure to sunlight, $3.33 \%$ for 
trauma and $1.66 \%$ for drug was considered as the aggravating factor. Cold climate increases Shita and Ruksha Guna which aggravates Vata \& Kapha in the body. Ekakushtha is Vata-Kaphaja disorder. So due to same Guna disease aggravates.

Family History: It was found that maximum patients i.e. $93.33 \%$ had no family history while remaining $6.66 \%$ had family history of Ekakushtha (psoriasis). Maharshi Sushruta also mentioned Kushtha as Adibala Pravritta Vyadhi[12] but strong correlation is still not established.

Dominanat Rasa in Ahara: This present study shows that maximum patients i.e. 53.33\% had Amla Rasa dominancy, then $16.33 \%$ patients had Lavana Rasa dominancy. Excessive use of Amla and Lavana rasa aggravates Pitta and Kapha dosha which leads to Raktadushti that causes the disease Ekakushtha. So it can be concluded that Amla and Lavana Rasa are the causative Rasa for the disease Ekakushtha.

Nidra: It was found that maximum patients i.e. $48.33 \%$ had Khandita Nidra (disturbed sleep). It may be due to itching, mental stress \& Vata aggravation. So it can be concluded that Ekakushtha (Psoriasis) causes Khandita Nidra (disturbed sleep).

Sharirika Prakriti: The assessment of Sharirika Prakriti revealed that maximum patients i.e., 44 patients $(73.33 \%)$ were of Vata-Kaphaja Prakriti. According to Acharya Charaka, Ekakushtha is the disease of Vata-Kaphaja Prakriti.[4] So, it can be inferred that Vata-Kaphaja Prakriti subject develops the disease more because of the similar Dosha.

Manasika Prakriti: During the assessment of Manasika Prakriti it was found that the most affected patients i.e. 63.33\% were having the Rajasika Prakriti. In Rajasika Prakriti person, Krodha and Shoka are major Mana Bhava so they become anxious or depressed quickly and these are the aggravating factors for Ekakushtha (psoriasis).

Mental status: It was observed that maximum patients i.e. $46.66 \%$ were depressed, $33.33 \%$ were anxious. As the psoriasis is a chronic disease and also suffers a mental and social trauma to the patient so maximum patients were depressed and anxious.

\section{Discussion on Results}

Asvedanama: $62 \%$ relief was observed in Group A, while it was $30.5 \%$ in group $B$. The result was statistically highly significant i.e., $\mathrm{p}<0.001$ in group $\mathrm{A}$ and significant i.e., $\mathrm{p}<0.01$ in group $\mathrm{B}$.

Mahavastu: 49\% relief was observed in Group A, while it was $21 \%$ in group B. The result was statistically highly significant i.e., $\mathrm{p}<0.001$ in group $\mathrm{A}$ and significant i.e., $\mathrm{p}<0.01$ in group $\mathrm{B}$.

Matsyashakalopamam: $61.5 \%$ relief was observed in Group A, while it was 26\% in group B. The result was statistically highly significant i.e., $\mathrm{p}<0.001$ in group A and significant i.e., $\mathrm{p}<0.01$ in group $\mathrm{B}$.

Krishna Aruna Varna: 51.5\% relief was observed in Group A, while it was $23.5 \%$ in group B. The result was statistically highly significant i.e., $\mathrm{p}<0.001$ in group $A$ and significant i.e., $\mathrm{p}<0.01$ in group $\mathrm{B}$.

Kandu: $68 \%$ relief was observed in Group A, while it was $25 \%$ in group B. The result was statistically highly significant i.e., $\mathrm{p}<0.001$ in group $\mathrm{A}$ and significant i.e., $\mathrm{p}<0.01$ in group $\mathrm{B}$.

Rukshata: 55\% relief was observed in Group A, while it was $21 \%$ in group B. The result was statistically highly significant i.e., $\mathrm{p}<0.001$ in group $\mathrm{A}$ and significant i.e., $\mathrm{p}<0.01$ in group $\mathrm{B}$.

Candle grease Sign: 55\% relief was observed in Group A, while it was $26.6 \%$ in group B. The result was statistically highly significant i.e., $\mathrm{p}<0.001$ in group $\mathrm{A}$ and significant i.e., $\mathrm{p}<0.01$ in group $B$.

Auspitz's Sign: $56 \%$ relief was observed in Group A while it was $28.9 \%$ in group B. The result was statistically highly significant i.e., $\mathrm{p}<0.001$ in group $\mathrm{A}$ and significant i.e., $\mathrm{p}<0.05$ in group $B$.

\section{CONCLUSION}

Vamana is best Shodhana Karma in Kapha predominant disease. Ekakushtha is recurrent in nature, so repeated Shodhana Karma is needed for eradication of the disease. No adverse effects were observed in the present clinical study. So it can be concluded that the present study is safe and very effective for the management of Ekakushtha (Psoriasis). Further extensive and large scale studies are recommended.

\section{REFERENCES}

1. Kushwaha Harishchandra, Charaka Samhita, Vol II (Chikitsasthana-7/21), Reprint edition, Varanasi; Chaukhamba Orientalia; 2016. p. 198.

2. Walker Brian R. Colledge Nicki R., Ralston Sturat H. and Penan Ian D., Davidson's Principles and Practice of Medicine, 22nd edition, UK; Churchill Livingstone Elsevier; 2014. p. 28.

3. Get the facts about psoriasis \& psoriatic arthritis; National Psoriasis Foundation; [cited 2021 Oct 3]. Available from: https://www.psoriasis.org/ psoriasis-statistics

4. Kushwaha Harishchandra, Charaka Samhita, Vol II (Chikitsasthana-7/31), Reprint edition, Varanasi; Chaukhamba Orientalia; 2016. p. 200.

5. Kushwaha Harishchandra, Charaka Samhita, Vol I (Sutrasthana-25/40), Reprint edition, Varanasi; Chaukhamba Orientalia; 2016, p. 353.

6. Kushwaha Harishchandra, Charaka Samhita, Vol II (Chikitsasthana-7/9-10) Reprint edition, Varanasi; Chaukhamba Orientalia; 2016, p. 197. 
7. Patil Vasant C., Principles and Practice of 10. Singh Amritpal, Bhavprakash Nighantu, Guduchyadi Panchakarma, Reprint edition, New Delhi, Chaukhambha Publications 2019; p 340, 403. Varga, $1^{\text {st }}$ edition, Varanasi, Chaukhambha Orientalia 2007; p. 91.

8. Singh Amritpal, Bhavprakash Nighantu, Haritkyadi Varga, $1^{\text {st }}$ edition, Varanasi, Chaukhambha Orientalia 2007; p 12.

11. Kushwaha Harishchandra, Charaka Samhita, Vol II (Kalpasthana-1/13) Reprint edition, Varanasi; Chaukhamba Orientalia 2016; p 858.

9. Kushwaha Harishchandra, Charaka Samhita, Vol I (Sutrasthana-26/43) Reprint edition, Varanasi; Chaukhamba Orientalia 2016; p 386.

12. Murthy K.R.S., Sushruta Samhita, Vol 1 (Nidanasthana-5/31), Reprint Edition, Varanasi; Chaukhambha Orientalia; 2016. p. 501.

\section{Cite this article as:}

MD Haidar, Sukumar Ghosh, Supriya Bhattacharya, Asish Kumar Das, Rajarshi Chaudhuri. A Comparative Clinical Study on Vamana And Virechana Karma In The Management of Ekakushtha With Special Reference To Psoriasis. International Journal of Ayurveda and Pharma Research. 2021;9(Suppl 1):27-35.

https://doi.org/10.47070/ijapr.v9iSuppl1.2109

Source of support: Nil, Conflict of interest: None Declared

\section{*Address for correspondence Dr. MD Haidar \\ PG Scholar, \\ Department of Panchakarma, Institute of Post Graduate Ayurvedic Education \& Research at Shyamadas Vaidya Shastra Pith, Kolkata, West Bengal, India. Email: dr.mdhaidar@gmail.com Contact no. 9038606038}

Disclaimer: IJAPR is solely owned by Mahadev Publications - dedicated to publish quality research, while every effort has been taken to verify the accuracy of the content published in our Journal. IJAPR cannot accept any responsibility or liability for the articles content which are published. The views expressed in articles by our contributing authors are not necessarily those of IJAPR editor or editorial board members. 